\title{
The Relationship Between Credit Risk Management Practices And Profitability In Malaysian Commercial Bank`S
}

\author{
Ali Taha Oleiwi, Maimuna Ali, Sarmad Hamza Jassim, Mohammed Hayder Nadhim, Ganama \\ Moustapha Gueme, Nazarudin Bujang
}

\begin{abstract}
This research scope looks into credit risk management and its effect on a specific group of banks with intensive commercial activity within Malaysia. Yearly reports from 8 different banks that rely on secondary data gathered from the span of 3 years (2015-2017), form the essence of this research. Return on assets (ROA) was primarily used in this research to measure profitability. Also, two credit risk measuring methods were used, loan loss provisions ratio (LLPR) and ratio of capital adequacy (CAR). From the results we deduced that commercial bank's profitability related positively to capital adequacy ratio and loan loss provision ratio. Therefore, the research calls upon the need of new management structure that optimally keep credit risk in check and boost banks profitability.
\end{abstract}

Keywords: Credit Risk Management, Commercial Banks, Financial Performance (Profitability), Malaysia

\section{INTRODUCTION}

Credit risk management is the process of eliminating all potential elements of risk surrounding any type of investment. The last financial global meltdown highlighted how vital is credit management to the world of finance. Not to mention how increasingly it's becoming a concerning issue that requires ingenious risk management methods.

Therefore the main objective of this paper is to explore the extent of how effective is current credit risk management practices on commercial banks profitability. This research was designed and developed using a quantitative research design method. Also, we used cross-sectional survey techniques to collect all the necessary data.

Generally, banks face a lot of obstacles, chief among them is credit risk and also considering the fact that credit is the number one source of income for most banks. So

Revised Manuscript Received on April 19, 2019.

Ali Taha Oleiwi, Department of Business Administration, Faculty of Technology management and Business, University Tun Hussein Onn, Johor, Malaysia.

Maimuna Ali, Department of Business Administration, Faculty of Technology management and Business, University Tun Hussein Onn, Johor, Malaysia.

Sarmad Hamza Jassim, Department of Business Administration, Faculty of Management and Economics, Almustansiriyah University, Baghdad, Iraq.

Mohammed Hayder Nadhim, Department of Business Administration, Faculty of Technology management and Business, University Tun Hussein Onn, Johor, Malaysia.

Ganama Moustapha Gueme, Department of Business Administration, Faculty of Technology management and Business, University Tun Hussein Onn, Johor, Malaysia.

Nazarudin Bujang, Department of Business Administration, Faculty of Technology management and Business, University Tun Hussein Onn, Johor, Malaysia. without the right strategies put in place, the damage or lose could exceed all desired goals. After reviewing a plethora of studies conducted on the field, we found a lack of data that coherently explain the relation between profitability and credit risk on commercial banks within Malaysia. Thus, necessitating the need for conducting this research (1).

Managers of commercial banks should strengthen their knowledge on credit risk management through effective training.And continuous learning about the latest trends and techniques, to improve the overall performance of their banks and mitigate any chance of credit risk (2).

\section{OBJECTIVE OF THE STUDY}

The overall purpose of this study, first is, to determine the current risk management practices in Malaysian commercial banks. Second, to examine the relationship between credit risk management and profitability in Malaysian commercial banks. By testing the profitability through financial ratios and reviewing current risk management practices of Malaysian local commercial banks. Include a research paper area span 2015 until 2017. As a financial institutions.

\section{LITERATURE REVIEW}

\section{A. Definition of Credit Risk Management}

Nowadays, the main risk that faced by the most of banks is the credit risk and is can be defined as: probability of borrower fail to meet their obligation (principal, interests, and commissions), on time or in accordance with the agreed terms. Banks are required by law to maintain Loan Loss Reserves. In order to cover the losses caused by the loans. Credit risk arises from a debtor being unlikely to pay its obligations or its financial capacity deteriorated resulting in an economic loss for the bank (3).

\section{B. Theory of Risk}

The main objective of risk management is to mitigate any risk coming from profit volatility, and avoid or diminish the impact of any huge loses. Standard procedures of risk management is pinpointing areas of risk, measuring the scale of effect. And, deploy accordingly the right strategies (4). It all begins with first inspecting and understanding the origin of any potential risks or imminent threats, then 
starting off the process of risk managing. Second, the measurement must quantify the risks pinpointed during the identification phase. For instance, an individual needs to measure the probability of the actual default and comprehend to what extent the risk effects could cause the probability of default. At this stage, statistical analysis must be implemented for accurate measuring of risk measurement (5).

\section{The Current Risk Management Practices}

The Central Bank of Malaysia (BNM) completed the credit risk review standard in January 2018 to replace the 2001 procedure. The standards of the review update multiple aspects of financial institution credit risk management practices (Figure 1). These standards include a variety of products, increase the cross-border business of financial institutions, and further deepen the domestic capital market, which is an alternative source of funding for large banking institutions (6).

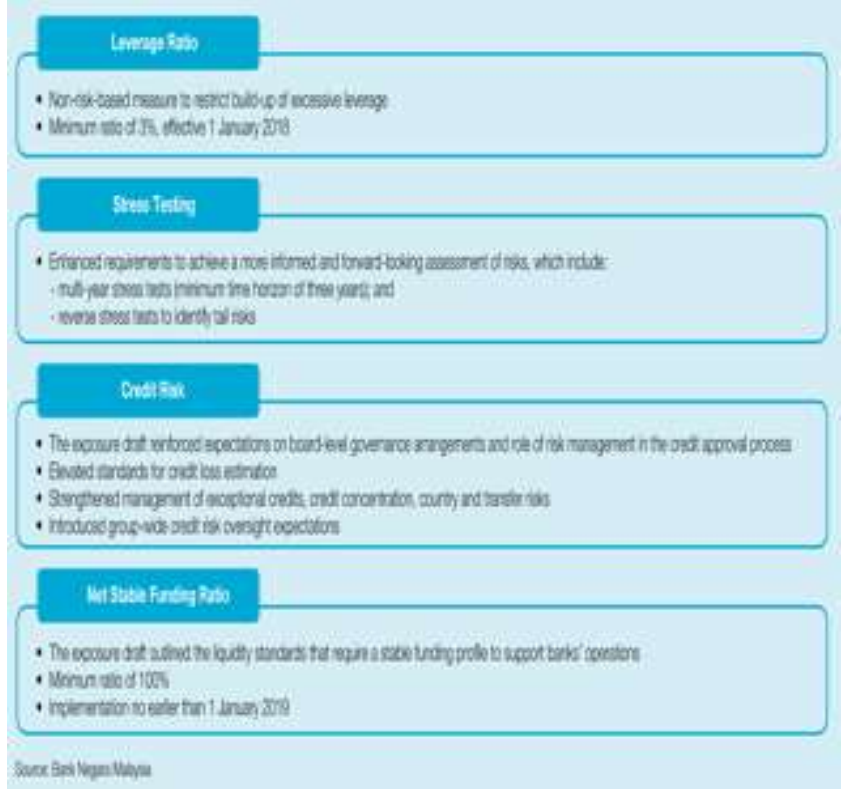

Figure 1. Summary of Key Prudential Standards Issued (6).

The revised standard requires financial institutions to adopt a more advanced credit loss estimation method and also supports the implementation of Malaysia Financial Reporting Standard 9: Financial Instruments (MFRS 9), which came into force on January 1, 2018. Forward-looking approach According to MFRS 9's new impairment criteria, financial institutions are expected to estimate expected credit losses during the credit facility, taking into account broader macroeconomic developments. (Figure 2). Although MFRS 9 is expected to have higher provisions, the impact on bank earnings and capital is estimated to be within bank expectations. The regulatory reserve requirement that banks are allowed to offset the increase in provisions will largely mitigate this effect. Therefore, despite the higher regulations, Banks continue to maintain capital levels well above the regulatory minimum (6).

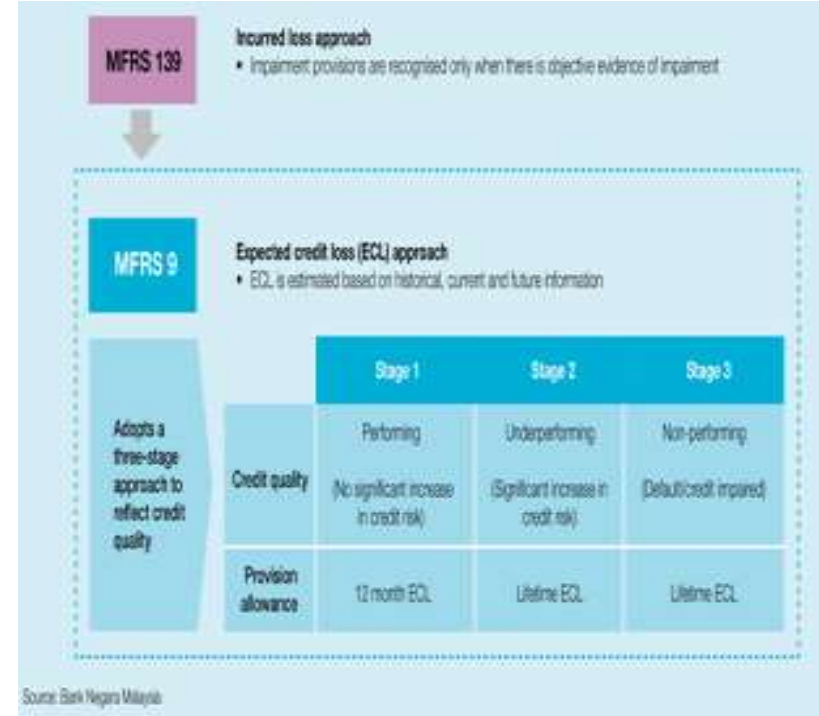

Figure 2. MFRS 9 Provisioning Requirements (6).

\subsubsection{Risk Concept}

It's inevitable for most companies to venture into business and operate without incurring any type of risk, considering the elements of uncertainty and complexity that come along with any business. Among all types of business operations, banks are the most susceptible to risk, given how volatile their environments and operations could be. Besides, the high level of participation and competition in the banking industry (7).

Organizations that implement succession planning recognize employees with talent and potential, by setting them in the right environment to nature their talent and take their potential to the next level. Also consistently providing them with opportunities to gain additional skills and knowledge (8). Especially leadership skills. Oftentimes, applying all measures doesn't mean in most cases a complete and total avoidance or elimination of risk, there is always a possibility of failure in the strategies or methods used (9). Hence, a company must manage risk with priorities set in place and strategies that corporate all the possible scenarios to mitigate and reduce risk, if elimination proves to be elusive.

\subsubsection{Credit Risk Management}

Many researchers had come out with reasons of bank failures and recognized numerous issues (10). Issues associated with loans. Specifically poor credit risk management policies, have been identified as the major explanations behind banking problems.

Majority of bank's equity is made up of Loans. This means any decline in the quality of loans can bring serious problems in the banking business. One factor that exists between financial institutions and borrowers is information asymmetry. This phenomenon makes it difficult for banks to identify creditable borrowers from bad ones. Therefore banks must put systems in place in order to analyze and evaluate the creditworthiness of borrowers to avoid adverse selection and moral hazard which are products of information asymmetry (11). 


\subsection{Conceptual Framework}

All the methods used here are contingent upon "dependent variables" and "independent variable" which are both similar but applied differently. The dependent variable depends on the independent variable, as shown in Figure 3. The focus of these procedures is to determine the numbers of these two types.

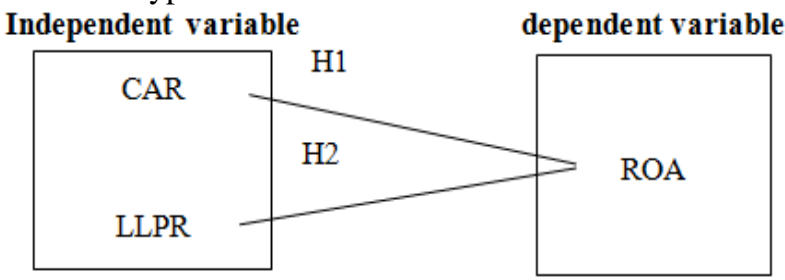

Figure 3. Conceptual Framework

\section{METHODOLOGY}

A research paper without an appropriate methodology is completely meaningless and far from achieving any impact. It sets all the necessary principles a researcher needs to carry out his study from collecting to analyzing data. To clearly identify the link between profitability and credit risk, the researcher chose to employ a quantitative method which is precisely subtle for the purpose of this paper.

\section{A. Research Design}

There is a lot of research designs that specifically aimed at solving business problems (12). Research designs are threefold, depending on how researches formulate their approaches and goals in a given paper. They are explanatory research, descriptive research and exploratory research(13).

\section{B. Sampling Frame of Study}

To have the best outcomes, a researcher should pick a population with metrics that serve the purpose of his research like specific class of people or events. A list of the all factors deduced from population samples is called a sampling frame, thus it's the precursor of any effective sample. It is a list of all local commercial banks in Malaysia with a population that can be sampled. The target population of this study was the local commercial banks in Malaysia. Therefore, the target population of this study which are the commercial banks that contribute to the process of economic development process.

The primary focus of this study is utilizing financial ratios to test and delve into all banks with commercial activities. The total number of banks that are deemed commercial in Malaysia are 25. They are split into 8 local banks and 17 foreign banks. So this is a census study of all commercial banks as they are forming the target population of this research. As of 2017, the number of fully functioning commercial banks is 8 , all of which are licensed and locally based. The latest bank to join the group of local commercial banks is Hong Leon after it has completed its merger with EON Bank in July 2011. To commence the study, we collected all data from local commercial banks and it covered the span of 3 years from 2015 until 2017. Local commercial banks include:

1) Hong Leong Bank Berhad.

2) RHB Bank Berhad.

3) Public Bank Berhad.
4) Malayan Banking Berhad (Maybank).

5) CIMB Bank Berhad.

6) AmBank (M) Berhad.

7) Alliance Bank Malaysia Berhad.

8) Affin Bank Berhad.

\section{Unit of Measurement}

In this paper, the unit of measurement was used the formulas below (Table 1) to find out indicators of the depended and in depended variable. The independent variable represents credit risk management and dependent variable.

Table 1. Unit of measurement

\begin{tabular}{lll}
\hline No & Indicators & Formulas \\
\hline 1 Independent & CAR & $\begin{array}{l}\text { Total capital/ } \\
\text { Risk-Weighted-Assets } \\
\text { Total of Risk provisions made } \\
\text { during year/ Total Income* 10C }\end{array}$ \\
& LLPR & net income/total Assets \\
\hline 2 Dependent & ROA & \\
\hline
\end{tabular}

\section{Data collection method}

We developed and designed all the tools necessary to obtain the information in this study. Annual reports measure the performance of given bank over an extend period of time so they proved to be a valuable source of information to collect data from. Financial statement reports of central bank of Malaysia, and the list of local commercial banks in Malaysia.

\section{E. Data Analysis}

The essence of any research is data analysis. After the data were collected, the analysis immediately followed to prove whether the hypothesis is true or false. The process was executed using IBM Statistical Packages for Social Science (SPSS), Statistics version 20.0. It's worth noting that descriptive and correlation analysis was used.

\section{RESULTS AND FINDINGS}

This section of the study had analyzed and discussed the findings that were extracted from the financial statements we collected. The annual reports were constructed based on the paper objectives that have been discussed in section 1 . The data collected were analyzed using "IBM Statistical Package for Social Science (SPSS) Statistics" version 20.0. The results gathered from this paper formed the foundation on which a conclusion was formulated. The types data analysis used were twofold, including, correlation analysis and descriptive analysis.
A. The Current Risk Management Practices
1) Profile of the Selected Banks
a) Hong Leong Bank Berhad 
Counterparty credit risk is the possibility of the Counterparty defaulting on their obligations towards the Bank. To control over-exposure of counterparty credit risk, credit limits are established for each trading counterparty. The credit limits are determined individually based on its credit strength and profile, which also takes into consideration the Group's and the Bank's risk and trading strategies (21).

Appropriate methodologies have been executed to measure counterparty credit risk against credit limits of each trading counterparty. These measurement methodologies implemented are in line with BNM's Capital Adequacy Framework on the treatment of counterparty credit risk. The Group and the Bank also engage in netting and margining agreements with major trading counterparties to mitigate counterparty credit risks (21).

\section{a) RHB Bank Berhad}

To ensure low levels of risk, the bank's decision for grating facilities take into account other metrics aside from only depending on the collateral given. All credit lines are granted based on the how financially the client is fit to carry out his obligations, source of the repayment as well as credit history of the client. Collaterals are used as much as possible to mitigate the credit risk assumed, subject to the Group's policy of managing collateral eligibility for credit risk mitigation (20).

The valuation of the collateral is measured and controlled through the policy of collateral valuation set by the bank. The policy determines the valuation frequency for variety of collaterals/securities, based on metrics like the acceptability and volatility of collateral values and related products (20).

\section{a) Public Bank Berhad}

The bank follows a completely different approach in providing credit facilities by utilizing methods formed on the basis of client's credit standing, debt servicing ability and the capacity for disposal of assets deemed as collateral, instead of majorly relying on credit risk mitigation (19).

The banks secures various types of collateral, the main ones are following:

1) Residential property charges under residential mortgage.

2) Charges for funding properties under commercial property loans/financing.

3) Ownership claims for vehicles funded under motor vehicle financing.

4) Initiates over securities from registered exchange under share margin financing.

5) Control over all business assets such as properties, inventories, and trade receivables (19).

\section{b) Malayan Banking Berhad (Maybank)}

Maybank sustain a healthy capital adequacy by employing the principles of BNM's Capital Adequacy and Basel II Capital Adequacy Frameworks for calculating the ratios. Both Frameworks were released on 4 August 2017 and 2 March 2017.

The total RWA are calculated with the following approaches:

1) Credit risk Approach (under Standardized Approach).

\section{2) Market risk Approach (under Standardized} Approach).

3) Operational risk (under Basic Indicator Approach).

The least compulsory requirements of capital adequacy with consideration to Tier one and total Capital in 2017 were $4.5 \%, 6.0 \%$ and $8.0 \%$ of total RWA. It's worth mentioning that in 2016 it was the same $4.5 \%, 6.0 \%$ and $8.0 \%$ of total RWA (18).

\section{a) CIMB Bank Berhad}

The bank has a standard policy that involves rating all exposures via specific internal rating models .The primary function of these models is to regulate and improve the overall effectiveness of credit underwriting and decisionmaking process for the Group's retail and non-retail exposures (17). Their techniques include the following three points:

\section{(1) Credit Risk Mitigation}

The bank utilize different credit risk mitigation methods such as appropriate credit structuring and posting of collaterals are among the various techniques the bank utilize for credit risk mitigation (17).

\section{(2) Collaterals/Securities}

All assets, physical and financial fall under collaterals. Physical collaterals are all valuable recourses that don't necessarily generate cash such as properties, lands, equipment's and vehicles. Whereas, financial collaterals are made up of securities, bonds and cash deposits or any investments maintained with purpose of financial gain. Guarantors accepted must meet the guidelines of (RiskWeighted Assets) and BNM's CAF (Basel II - RiskWeighted Assets).

\section{(3) Collateral Valuation and Management}

The bank has set clear guidelines and strategies that administer the fitness of borrowers. Minimum operational requirements for collaterals must be fulfilled as effective factors of risk mitigation (17).

\section{a) AmBank (M) Berhad}

The main driver behind credit risk management is recognizing and containing all possible threats resulting from credit risk by identification and measurement. And also shielding the bank from any potential exposure through Risk Appetite Framework and other related credit strategies. Risk recognition of non-retail credits starts with checking and devaluing the ability of the borrower to meet his financial duties through credit rating models (16).

To ensure a fully effective credit risk management and to the betterment of major portfolios, our rating models has been update to streamline the following:

1. Loan/financing loss provision calculation

2. More accurate assessment of individual's ratings.

3. Improvement of pricing models.

4. Increasing the performance of the portfolio management.

Published By: 
b) Alliance Bank Malaysia Berhad

The Group overcome Capital Adequacy by applying basic Indicator approach for capital Adequacy computation. All the bank's ratios of capital adequacy are calculated following the guidelines of Malaysia central bank of Capital Adequacy Framework which was developed on 28 November 2012.

The Framework determines the right approach for calculating regulatory capital adequacy ratio and setting the extent of ratios that all banks must operate within (15).

unfortunately, dealing with counterparties introduce and increases the chances of credit risk from activities such as interbank market transactions or using instrument of derivatives to minimize the risk of loans. Consequently, the size of credit risk exposure with regard to derivatives is equal to the carrying size of assets in the financial statements (15).

\section{c) Affin Bank Berhad}

Banks usually exercise different policies that help them minimize and keep credit risk controlled. Internal bounders along with clear lending guidelines are set between The Group and the Bank, to firmly control and manage exposures of any magnitude. Meanwhile, keeping all possible unwarranted accumulations of credit risk away from its portfolio. Considering the volatility of the market and the vagueness of economic climate, all risks should be regularly checked with all boundaries reviewed on annual basis(14).

\section{B) Reliability Analysis}

Reliability measures the accuracy of the research paper instrument methods according to the purpose of the study. To assess and evaluate the reliability of the indicators, we implemented cronbach's alph as shown in Table 2. The test performed in actual study. This is to ensure the coefficient value which had been proposed by (5).

Table 2. Reliability Coefficient Value

\begin{tabular}{ll}
\hline Cronbach's & Internal Consistency \\
\hline $0.9-1.0$ & Excellent \\
$0.7-0.8$ & Good \& Acceptable \\
$0.6-0.7$ & Acceptable \\
\hline
\end{tabular}

The data constructed is considered as acceptable when the coefficient of Cronbach's Alpha is more than 0.6 (5).

Therefore, we have a concrete reasons for conducting this research. On the other hand, the researcher must revise the reports if the coefficient of Cronbach's Alpha is less than 0.6. Due to the reason that there might be redundant or unclear indicator in the annual report. There were 8 Banks that contributed to this study.

Table 3. Reliability of the Study

\begin{tabular}{cccc}
\hline \multicolumn{2}{c}{$\begin{array}{c}\text { Cronbach' } \\
5\end{array}$} & $\begin{array}{c}\text { No. of } \\
\text { indicators }\end{array}$ & $\begin{array}{c}\text { No. of } \\
\text { Banks }\end{array}$ \\
\hline 0.738 & 5 & 8 \\
\hline
\end{tabular}

Based on the Table 3 the Cronbach's of the study was 0.738 . The data has been collected from 8 banks in order to test the level of reliability. Since the Cronbach's Alpha for the study was 0.738 . As a result, the reliability instrument used in this study is considered acceptable.

\section{Descriptive Analysis}

Descriptive analysis is employed to pinpoint the paper targets. It's statistical method that represents a number of techniques to effectively outline a given set of data. This analysis shows a summary of the local commercial banks credit risk management and profitability. The data sets in link to measure the average of mean value for both dependent and independent variables as shown in Table 4.

Table 4. Mean Value Analysis

\begin{tabular}{ccl}
\hline \multicolumn{3}{l}{ Local commercial banks } \\
\hline CAR & LLPR & ROA \\
\hline 3.87 & 24.72 & 0.03 \\
\hline
\end{tabular}

\section{Correlation Analysis}

Correlation analysis is used to explore the practices of credit risk management (CAR, and LLPR) in relation to the profitability (ROA) of 8 Malaysians local commercial banks. It covers a period of 3 years, from 2015 to 2017.

Table 5. Correlation between CAR and ROA

\begin{tabular}{|c|c|c|c|c|}
\hline & & & CAR & ROA \\
\hline \multirow[t]{6}{*}{$\begin{array}{l}\text { Spearman's } \\
\text { tho }\end{array}$} & CAR & $\begin{array}{l}\text { Correlation } \\
\text { Coefficient }\end{array}$ & 1.000 & $.579^{\prime \prime}$ \\
\hline & & $\begin{array}{l}\text { Sig. } \\
\text { (2-tailed) }\end{array}$ & . & .000 \\
\hline & & $\mathrm{N}$ & 24 & 24 \\
\hline & ROA & $\begin{array}{l}\text { Correlation } \\
\text { Coefficient }\end{array}$ & $.579^{\prime \prime}$ & 1.000 \\
\hline & & Sig. & .000 & .24 \\
\hline & & $\begin{array}{l}\text { (2-tailed) } \\
\mathrm{N}\end{array}$ & 24 & \\
\hline
\end{tabular}

The correlation analysis in Table 5 is done to correlate CAR and ROA to investigate the relationship of profitability indicator with credit risk indicators that are considered Independent variables. Thus examining the Table 5 there is a positive significant connection between CAR and ROA.

According to the Table 5 the p-value of t-statistic is below significance level (0.01). Further, it's consider accepted. As long as the p-value of t-statistic (0.000) is below the significance level (0.05). Thus, there is sufficient proof to deduce that the CAR is significant to ROA.

Table 6. Correlation between LLPR and ROA

\begin{tabular}{|c|c|c|c|c|}
\hline & & & CAR & ROA \\
\hline \multirow[t]{6}{*}{$\begin{array}{l}\text { Spearman' } \\
\text { s rho }\end{array}$} & LLPR & $\begin{array}{l}\text { Correlation } \\
\text { Coefficient }\end{array}$ & 1.000 & $\begin{array}{l}.883^{\circ} \\
8\end{array}$ \\
\hline & & $\begin{array}{l}\text { Sig. } \\
\text { (2-tailed) }\end{array}$ & . & .000 \\
\hline & & $\mathrm{N}$ & 24 & 24 \\
\hline & ROA & $\begin{array}{l}\text { Correlation } \\
\text { Coefficient }\end{array}$ & $.883^{88}$ & 1.000 \\
\hline & & Sig. & .000 & ${ }^{\circ}$ \\
\hline & & $\begin{array}{l}\text { (2-tailed) } \\
\mathrm{N}\end{array}$ & 24 & 24 \\
\hline
\end{tabular}

The correlation analysis in Table 6 is done to correlate LLPR and ROA to investigate the relationship of profitability indicators with credit risk indicators that are considered Independent variables. Thus there is a positive significant connection between LLPR and ROA. 
According to the Table 6 the p-value of t-statistic is below significance level (0.01). Further, it`s consider accepted. As long as the p-value of t-statistic (0.000) is below the significance level (0.01). Thus, there is sufficient proof to deduce that the LLPR is significant to ROA.

\section{E. Hypothesis Testing}

Previous researches have been inclusive in the relationship between credit risk management and profitability of commercial banks in Malaysia. So investigating the topic was inevitable. The study was carried out using data gathered from the extent of 3 years, 2015 to 2017. In the previous section, we have explained all the indicators which have been selected to present credit risk management and profitability of commercial banks. By examining the findings, the following hypotheses is formed:

1) Hypothesis 1: CAR has a significant relationship with ROA

As we stated before, CAR is an indicator of credit risk management and ROA is an indicator of profitability. This hypothesis is used to find any possible link between profitability and credit risk management of commercial banks.

The correlation analysis in Table 7 between CAR and ROA to investigate the relationship between the indicators of profitability and credit risk that are considered Independent. As it appears, there is a positive significant connection between CAR and ROA.

Table 7. Correlation coefficient between the CAR and ROA

\begin{tabular}{lll}
\hline Hypothesis & $\begin{array}{l}\text { Spearman } \\
\text { Correlatio } \\
\text { n }\end{array}$ & $\begin{array}{l}\text { P-vahe } \\
\text { (Sig.) }\end{array}$ \\
\hline $\begin{array}{l}\text { There is a significant positive } \\
\text { connection between the CAR and }\end{array}$ & .579 & 000 \\
ROA among local commercial \\
banks in Malaysia (at the level of \\
significant $\alpha=0.01$ ).
\end{tabular}
significance level (0.01). Further, it`s consider accepted. As long as the p-value of t-statistic (0.000) is below the significance level (0.01). Thus, there is sufficient proof to deduce that the CAR is significant to ROA.

To test the hypothesis, we utilized spearman's Correlation. Table 7 shows that the correlation coefficient between the CAR and ROA equalize .579 and the p-value (Sig.) equalize 0.000. The p-value (Sig.) is less than 0.01, so the correlation coefficient is statistically significant at ?= 0.01 . We can deduce that there is a significant positive connection between the CAR and ROA among local commercial banks in Malaysia (at the level of significant ? = $0.01)$

2) Hypothesis 2: LLPR has a significant relationship with ROA

LLPR and profitability are funneled through the system of indicators to verify whether there is any possible link between them in commercial banks.

The correlation analysis in Table 8 between LLPR and ROA to investigate the relationship of profitability
According to the Table 7 the p-value of t-statistic is below

indicators with credit risk indicators. Thus there is a positive significant connection between LLPR and ROA.

Table 8. Correlation coefficient between the LLPR and ROA

\begin{tabular}{lll}
\hline Hypothesis & $\begin{array}{l}\text { Spearman } \\
\text { Correlation }\end{array}$ & $\begin{array}{l}\text { P-vahue } \\
\text { (Sig.) }\end{array}$ \\
\hline $\begin{array}{l}\text { There is a significant positive } \\
\text { connection between the LLPR and }\end{array}$ & .000 \\
ROA among local commercial & \\
banks in Malaysia (at the level of & \\
significant $\alpha=0.01$ ). & & \\
\hline
\end{tabular}

According to the Table 8 the p-value of t-statistic is below significance level (0.01). Further, it's consider accepted. As long as the p-value of t-statistic (0.000) is below the significance level (0.01). Thus, there is sufficient proof to deduce that the LLPR is significant to ROA.

\section{F). Summary of Hypothesis Testing}

Considering the objective and the scope of this research, the obtained findings are shown in Table 9.

\section{Table 9. Summary of hypothesis testing result}

\begin{tabular}{lll}
\hline Hypothesis & Statement & Findings \\
\hline H1 & $\begin{array}{l}\text { There is a positive significant } \\
\text { connection between CAR and } \\
\text { ROA. }\end{array}$ & \\
H2 & $\begin{array}{l}\text { There is a positive significant } \\
\text { connection between LLPR } \\
\text { and ROA. }\end{array}$ & \\
& & \\
\hline
\end{tabular}

These two determinants show that CAR have a positive relationship with ROA. In comparison, the relationship between LLPR and ROA came as positive too.

G. Summary of Statistical Analysis

Table 10. Summary of Statistical Analysis

\begin{tabular}{lll}
\hline Hypothesis & $\begin{array}{l}\text { Type of } \\
\text { Relationship }\end{array}$ & \\
\hline Hl: CAR has a & Positive & Significant \\
significant connection & & \\
with ROA. & & \\
H2: LIP has a & Positive & Significant \\
significant connection & & \\
with ROA. & & \\
\hline
\end{tabular}

The aim of this study is twofold. Firstly, reviewing the strategies of credit risk for local commercial banks and assess their effectiveness in relation to the profits. With that end in mind, a bank performance will be measured in respect to its ROA.

By utilizing the indicators obtained from the banks and testing them through descriptive/correlation analysis, we discovered that a bank performance is strongly tied to its credit risk strategies demonstrated by the link between profitability and credit risk. Refer to Table 10 They show the average of ROA in local commercial banks. Which is quite high in relation to the other indicators.

Secondly, exploring the relationship of credit risk practices for Malaysian local commercial banks performance. As shown in Table 10 the results reveal the 
effects of the determinants on ROA. This summarization reveals that CAR and LLPR both has a significant connection with return on assets.

\section{CONCLUSION}

In the end, the essence and purpose of this paper has been successfully achieved, through reviewing and studying the various effects of both dependent and independent variables of credit risk on the profitability among local banks in Malaysia. Ratio of loan loss provision and capital adequacy consisted the independent variables. We utilized descriptive and correlation analysis to examine the data. IBM Statistical Package for Social Science (SPSS) was the program of choice to obtain the results. The sample size was focused on the study of 8 local licensed banks with intensive commercial activates. The study covered a period of 3 years starting from 2015 - 2017. Besides, a discussions of all the results and conclusions along with a summary of statistical analysis have been stated in this paper.

Credit risk has proven in so many occasions how indispensable it is to all financial institutions. Nonetheless, different institutions prioritize it and utilize it differently. Thus, based on the findings of the study. We strongly recommend for maximum results, a full and regular credit assessment of clients at all times. Although it's a neglected area, most of credit exposures stem from failing to thoroughly checking client's credit status.

Credit risk management shouldn't stop at a certain level or after achieving a desired result. It should always be active and enhanced regularly. That way, a bank will be able to carry out its operations and perform its services without worrying about the issues and problems of any credit nature.

\section{REFERENCES}

1. Ogboi C, Unuafe OK. Impact of credit risk management and capital adequacy on the financial performance of commercial banks in Nigeria. Journal of emerging issues in economics, finance and banking. 2013;2(3):703-17.

2. Haneef S, Riaz T, Ramzan M, Rana MA, Hafiz MI, Karim Y. Impact of risk management on non-performing loans and profitability of banking sector of Pakistan. International Journal of Business and Social Science. 2012;3(7)

3. Ozurumba BA. Impact of non-performing loans on the performance of selected commercial banks in Nigeria. Research Journal of Finance and Accounting. 2016;7(16):95-109.

4. Hanson SG, Kashyap AK, Stein JC. A macroprudential approach to financial regulation. Journal of economic Perspectives. 2011;25(1):3-28.

5. Mekasha G. Credit risk management and its impact on performance on Ethiopian commercial Banks. unpublished thesis (Msc), Addis Abeba University. 2011.

6. BNM. 2017.

7. Shingjergji A, Hyseni M. The determinants of the capital adequacy ratio in the Albanian banking system during 2007-2014. International Journal of Economics, Commerce and Management. 2015;3(1):1-10.

8. Lundblad CT, Zhu Z. Financial Intermediaries, Corporate Debt Financing, and The Transmission of Systemic Risk. 2017.

9. Erasmus CF. Determinants of asset quality in South African banks 2018.

10. Gizaw M, Kebede M, Selvaraj S. The impact of credit risk on profitability performance of commercial banks in
Ethiopia. African Journal of Business Management. 2015;9(2):59-66.

11. Mandala IGNN, Nawangpalupi CB, Praktikto FR. Assessing credit risk: An application of data mining in a rural bank. Procedia Economics and Finance. 2012;4:406-12.

12. Zopounidis C, Galariotis E, Doumpos M, Sarri S, AndriosopouloS K. Multiple criteria decision aiding for finance: An updated bibliographic survey. European Journal of Operational Research. 2015;247(2):339-48.

13. Boudriga A, Boulila Taktak N, Jellouli S. Banking supervision and nonperforming loans: a cross-country analysis. Journal of financial economic policy. 2009;1(4):286-318.

14. Annual Report of Affin Bank Berhad. 2017.

15. Annual Report of Alliance Bank Malaysia Berthed. 2017.

16. Annual Report of AmBank Berhad. 2017.

17. Annual Report of CIMB Bank Berhad. 2017.

18. Annual Report of Malayan Banking Berhad Maybank. 2017.

19. Annual Report of Public Bank Berhad 2017.

20. Annual report of RHB Bank Berhad. 2017.

21. Annual Report of Hong Leong Bank Berhad. 2017. 